1. Norden AD, Young GS, Setayesh K, et al. Bevacizumab for recurrent malignant glioma: efficacy, toxicity and patterns of recurrence. Neurology 2008;70:779-787.

2. Vredenburgh JJ, Desjardins A, Herndon JE, et al. Phase II trial of bevacizumab and irinotecan in recurrent malignant glioma. Clin Cancer Res 2007;13:1253-1259.

3. Pope WB, Lai A, Nghiemphu P, Mischel P, Cloughesy TF. MRI in patients with high-grade gliomas treated with bevacizumab and chemotherapy. Neurology 2006;66:1258-1260.

4. Prados MD, Lamborn K, Yung WKA, et al. A phase 2 trail of irinotecan (CPT-11) in patients with recurrent malignant glioma: a NABTC study. Neuro-Oncology 2006;8: 189-193.

5. Batchelor TT, Sorensen AG, diTomaso E, et al. AZD2171, a pan-VEGF receptor tyrosine kinase inhibi- tor, normalizes tumor vasculature and alleviates edema in glioblastoma patients. Cancer Cell 2007;11:83-95.

6. Stark-Vance V. Bevacizumab (Avastin) and CPT-11 (Camptosar) in the treatment of relapsed malignant glioma. Neuro-Oncology 2005;7:369.

7. Li JL, Sainson RC, Shi W, et al. Delta-like 4 Notch ligand regulates tumor angiogenesis, improves tumor vascular function, and promotes tumor growth in vivo. Cancer Res 2007;67:11244-11253

8. Macdonald DR, Cascino TL, Schold SC Jr, Cairncross JG. Response criteria for phase II studies of supratentorial malignant glioma. J Clin Oncol 1990;8:1277-1280.

9. Chi A, Norden AD, Wen PY. Inhibition of angiogenesis and invasion in malignant gliomas. Exp Rev Anticancer Ther 2007;7:1537-1560.

\title{
CORRECTION
}

\section{A case of ALS-FTD in a large FALS pedigree with a K17I ANG mutation}

In the Clinical/Scientific Note "A case of ALS-FTD in a large FALS pedigree with a K17I ANG mutation" by M.A. van Es et al. (Neurology ${ }^{\circledR} 2009 ; 72: 287-288$ ), K17I was incorrectly labeled as K171 in panels A and B of the figure. The editorial staff regrets the error. 


\section{Neurology}

\section{A case of ALS-FTD in a large FALS pedigree with a K17I ANG mutation \\ Neurology 2009;72;774 \\ DOI 10.1212/01.wnl.0000344282.98635.2d}

This information is current as of February 23, 2009

\section{Updated Information \&}

Services

Permissions \& Licensing

Reprints including high resolution figures, can be found at: http://n.neurology.org/content/72/8/774.full

Information about reproducing this article in parts (figures,tables) or in its entirety can be found online at:

http://www.neurology.org/about/about_the_journal\#permissions

Information about ordering reprints can be found online:

http://n.neurology.org/subscribers/advertise

Neurology ${ }^{\circledR}$ is the official journal of the American Academy of Neurology. Published continuously since 1951, it is now a weekly with 48 issues per year. Copyright. All rights reserved. Print ISSN: 0028-3878. Online ISSN: 1526-632X.

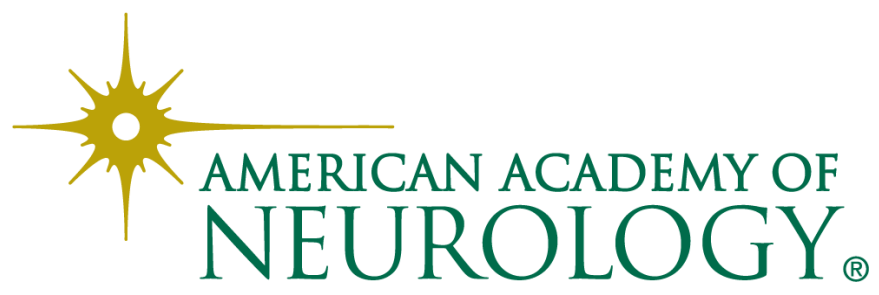

